\title{
Problemas Estéticos e Sociológicos da Música Eletroacústica*
}

HeRMAN SABBE

Vou falar-lhes do problema estético da liberdade de criação, que me parece estar no centro de qualquer reflexão teórica sobre esta instituição que é o estúdio de música eletrônica e constituir o dado fundamental, senão determinante, de sua política.

Os poderosos novos meios mnemotécnicos, que são para o pensamento musical a gravação eletromagnética do som sobre fita, seguida pela retenção de suas coordenadas na memória digital, já tiveram em parte - e teoricamente deveriam ter a longo prazo - a mesma influência que tiveram outrora a escrita musical primeiro e depois a técnica da edição musical sobre a evolução do pensamento, da produção e da distribuição musicais. Por isso, é necessário que uma reflexão atenta embase a política daqueles que têm a responsabilidade institucional desses meios.

A produção da música eletrônica (ou, mais amplamente, tecnológica), tal qual representada pela prática desses estúdios, é ambivalente por excelência. Por um lado, não há dúvida de que ela faz parte do conjunto desta evolução que chamamos cada vez mais de terceira revolução tecnológica ou revolução tecnotrônica, participando portanto de todas as suas conseqüências, a saber, principalmente, da automação, da estandartização das práticas e da mecanização das operações mentais. É necessário que todos se conscientizem devidamente disto. Por outro lado, a prática musical da eletrônica e da informática, inclusive institucionalizada (estudiomatizada!), constitui, dentro desta esfera tecnológica, uma possibilidade excepcional de salvaguardar valores emancipadores.

* Tradução do flamengo para o português por Álvaro Guimarães. 
Mas, para isso, é indispensável que, em relação às máquinas, a estética e a prática artística guardem, e até mesmo aumentem, uma certa distância - garantia de reflexão libertadora. Em poucas palavras: trata-se de submeter a máquina ao pensamento, e não o contrário. Pois é aí, nesta tentativa, que o estúdio/instituição enfrenta coerções de ordem econômica e ideológica que poderão restringir terrivelmente os limites no interior dos quais deverá desenvolver-se a ação libertadora da prática estética.

Façamos aqui um parêntese histórico. O nascimento da música eletrônica nos anos 50 atendia ao mesmo tempo a várias atitudes mentais e ideológicas do pós-guerra: uma fé renovada na tecnologia enquanto motor do progresso econômico e social; uma estática da abstração que levava a um grau zero da escrita musical, a qual tendia, por sua vez, à recusa de qualquer sentimento pré-estabelecido; uma ideologia da música pura, isto é, imaculada. A alegria dos pioneiros era triunfante, sua crença no poder libertador da nova prática era total. A partir dos próprios elementos do universo musical, reconstruir-se-ia musicalmente o universo. A decepção foi amarga quando ficou instaurada a contradição entre o potencial que se declarara erroneamente ilimitado e o caráter estereotipado dos resultados, pois estes ficaram circunscritos pelos imperativos da indústria eletrônica, que conseguiu reduzir o conjunto das possibilidades a alguns poucos tipos de aparelhos - limitação absolutamente arbitrária do ponto de vista da criação. Para máquinas que sabiam fazer tudo, os geradores de ondas sinusoidais e de ruído branco faziam bem pouco... E foi indispensável a força de invenção e de trabalho de alguns músicos notáveis para que se tirasse delas as poucas obras que continuarão a testemunhar essa aventura maravilhosa e fracassada.

E a história, esta história, não se estaria repetindo um quarto de século depois, debaixo de nossos olhos? A tecnologia eletrônica digitalisada e a automação informática nos são apresentadas mais uma vez com o mesmo rótulo ideológico, o da promessa de uma total apropriação da criação e livre acesso do criador ao potencial do conjunto da criação. Trata-se de denunciar essa nova ilusão de liberdade. Temos que reconhecer a evidência de que, para a indústria que produz essa tecnologia, a verdadeira liberdade de criação não importa. Para ela, trata-se, naturalmente, de contribuir, graças à automação, para a diminuição do tempo de reprodução do capital - e em particular, em aliança com a 
indústria cultural musical, "para a diminuição do tempo de consumo cultural. Para isto, não é no sentido de uma liberação, mas antes no de uma normalização sempre mais globalizadora, que será orientado o desenvolvimento desses aparelhos. Portanto, é apesar da tecnologia, contra as tendências que lhe atribui a ideologia industrial, que devemos utilizálos, para fins de criação liberadora; de certa forma, erguer a tecnologia contra si própria, desenvolver uma contra-habilidade, fazer delirar o computador.

Lembro que, há 15 anos, nós todos, que não recusávamos os novos meios, estávamos otimistas: as rotinas composicionais poderiam ser deixadas à máquina, possibilitando que o criador, assim liberado, passasse a um nível superior na hierarquia algorítmica e até mesmo desenvolvesse um trabalho de subversão criadora. Quanta ingenuidade! Como nos deixamos envolver pela ideologia! O que tivemos a audácia de desejar supunha de fato que a concepção das máquinas fosse adaptada àquilo que os criadores podiam imaginar, e não o contrário. Mas, se uma tal atitude não é impensável, ela deve enfrentar fortes coerções econômicas. Nos anos 50 e 60 , quem praticou a música eletrônica teve, de forma involuntária e inconsciente na maior parte dos casos, um papel histórico de experimentador num campo novo de investimento industrial promissor. Agora os dados estão lançados. O mercado eletrônico está aí, a tal ponto que os próprios estúdios correm o risco de serem as vítimas. A produção mercantil de sintetizadores, microprocessadores, mini-computadores tende de fato a desestimular, até mesmo a eliminar, o esforço de invenção individual dos pesquisadores - compositores, engenheiros, especialistas em informática - nos estúdios. Diante da oferta abundante de equipamentos confortavelmente prontos para uso - e exagera-se facilmente a velocidade dos progressos que só raramente são importantes e nunca essenciais - reduz-se ou até se anula a pesquisa de șoluções particulares.

Nossos estúdios, portanto, usam com frequiência meios de produção destinados a uma produção de massa. Eis aí um grave problema estético, mas de que não podemos tratar omitindo os aspectos ideológicos e os fenômenos econômicos que o condicionam. Tanto mais que considerações economicistas, inspiradas por conceitos ideológicos de produtividade e de rentabilidade, vêm também se opor ao que sobra de veleidades de particularização estética. Se o rendimento se impõe, não há como mandar, ou 
mais exatamente, deixar a máquina fazer, de lhe delegar o trabalho, de automatizar, o que quer dizer repetir, simplificar, fechar o círculo. A perspectiva, longe da liberação, é a robotização dos atos mentais da criação musical e, aliás, de modo mais geral, de qualquer criação cultural. Assim como a primeira revolução tecno-industrial provocou a alienação dos atos manuais do artesanato e seu desaparecimento, a atual poderá alienar e finalmente tornar obsoleta, senão folclórica, qualquer atividade intelectual criadora.

Ainda não chegamos lá. Mas, o que fazer? Como (re)agir? Encontramos uma forte reticência diante dos grandes meios por parte de muitos jovens que, por exemplo, voltaram a usar tesouras para fazer montagens manuais. Uma produção de caráter artesanal com um equipamento e um meio de produção industrializado é um contra-senso intencionalmente subversivo e, a meu ver, simpático. Mas não é a solução do problema que colocamos.

Porque não se trata de fugir da tirania da máquina, mas de quebrála. Porque não se trata de abandonar o computador nas mãos dos técnicos, especialistas em informática e outros tecnocratas, mas de torná-lo sensível às vontades criadoras. Porque não é o instrumento em si que é portador de ideologia, mas a maneira de concebê-lo e de conceber seu uso.

A este respeito, devemos denunciar a colaboração entre técnicos e músicos que, até agora, não passou de ilusão, ela também. No entanto, devemos tentar mais uma vez essa colaboração entre especialistas em informática e compositores, mas o compositor guiando o especialista e tornando-se ele mesmo um especialista em informática esclarecido.

Eis aí o hic. O que falta ao compositor, para esclarecer ou para se esclarecer, é uma teoria musical adequada. As teorias empíricas/cognitivas e a inteligência artificial musical estão engatinhando e do seu progresso depende grandemente o domínio da informática para fins musicais. Esta é a função que podem cumprir os estúdios, cuja vocação não é a de se tornar um lugar de exploração produtora, mas de investigação de aberturas.

Não é, por exemplo, na ausência de instrumentos ditos "acústicos", nem no tratamento eletrônico da voz humana, que reside, como querem alguns, o período de desumanização que os nostálgicos gostam tanto de comentar. A agressão à pessoa humana estaria antes na falta de liberda- 
de diante das restrições impostas pela máquina: o compositor programado, ao invés do compositor programador.

Temos que devolver ao homem criador todas as funções usurpadas pela máquina, por causa principalmente de programas insuficientes e inadequados. No alegado diálogo, devemos inverter os papéis. Já no "interativo", o músico tem o direito de abrir a boca, de retomar a palavra. Devemos agora devolver-lhe sem restrição. Quanto ao computador, que obedeça agora aos caprichos do espírito criador. Todos devemos lutar para isto.

A versão holandesa deste texto foi publicada no Boletim Gaudeamus (1982) e a versão francesa de 1984 não chegou a ser publicada. A tradução brasileira é de Jean Claude Bernardet (1984). Álvaro Guimarães (1999) utilizou as duas versões originais na tradução que ora publicamos. 